\title{
The Legal Definition of Disability
}

\section{Stanley Mutuma}

\section{(2) OpenEdition}

\section{Journals}

Electronic version

URL: https://journals.openedition.org/eastafrica/434

DOI: 10.4000 /eastafrica.434

ISSN: 2790-1076

\section{Publisher}

IFRA - Institut Français de Recherche en Afrique

\section{Printed version}

Date of publication: 1 October 2012

Number of pages: $27-30$

ISSN: 2071-7245

\section{Electronic reference}

Stanley Mutuma, "The Legal Definition of Disability", Les Cahiers d'Afrique de l'Est / The East African Review [Online], 46-1 | 2012, Online since 07 May 2019, connection on 10 December 2021. URL: http:// journals.openedition.org/eastafrica/434 ; DOI: https://doi.org/10.4000/eastafrica.434

This text was automatically generated on 10 December 2021.

Les Cahiers d'Afrique de l'Est / The East African Review 


\title{
The Legal Definition of Disability
}

\author{
Stanley Mutuma
}

\author{
Acronyms \\ ADA: Americans with Disability Act \\ PwD: Persons with Disability
}

\section{Introduction}

1 According to the United Nations Standard Rules on the equalization of opportunities for persons with disabilities, the term "disability" summarizes a great number of different functional limitations occurring in any population, in any country of the world. People may be disabled by physical, intellectual or sensory impairment, medical conditions or mental illness. Such impairments, conditions or illnesses may be permanent or transitory in nature. It is in the light of this that the United Nations adopted a convention on the rights and privileges of persons with disability. The convention adopted in 2006, which came into force in $2008,{ }^{1}$ states and recognizes that "disability" is an evolving concept which is subject to regular change. For instance due to the improvement in medical science and other new discoveries of how the human body works it is possible for doctors to determine that a person who does not seem to have any physical disability may be subjct to some mental or sensory impairment.

2 The Convention follows the civil law tradition, with a preamble in which the principle that "all human rights are universal, indivisible, interdependent and interrelated" of the Vienna Declaration and Programme of Action is cited, followed by 50 other articles. Unlike many UN covenants and conventions, it is not formally divided into parts.

Article 1 defines the purpose of the Convention as one that aims at promoting, protecting and ensuring the full and equal enjoyment of all human rights and fundamental freedoms by all persons with disabilities, and at promoting respect for their inherent dignity. Articles 2 and 3 provide definitions and general principles 
including communication, reasonable accommodation and universal design for those with disabilities.

4 Articles 4(32) define the rights of persons with disabilities and the obligations of states parties towards them. Many of these mirror rights affirmed in other UN conventions such as the International Covenant on Civil and Political Rights, International Covenant on Economic, Social and Cultural Rights or the Convention Against Torture, but with specific obligations ensuring that they can be fully realized by persons with disabilities.

5 Rights specific to this convention include the rights to accessibility, including information technology, the rights to live independently and be included in the community (Article 19), to personal mobility (Article 20), habilitation and rehabilitation (Article 26), and to participation in political and public life, and cultural life, recreation and sport. The recognition before the law for the countries that have ratified this treaty is found under Article 12. In effect it means that this is a legal document that can be used to give effect to the rights and privileges found within it.

6 The Americans with Disability Act (ADA), ${ }^{2}$ on the other hand, provides the definition of disability as being: statutory with respect to an individual. Here the term "disability" is taken to mean:

- a physical or mental impairment that substantially limits one or more of the major life activities of such individual;

- a record of such an impairment; or

- being regarded as having such an impairment.

7 ADA's definition allows for persons who actually have physical or mental impairments that substantially limit one or more major life activities to be included in this definition. The focus under this first part of the definition is on the individual, to determine if (s)he has a substantially limiting impairment. To fall under the first part of the definition, a disabled person must exhibit the following three elements:

- that (s)he has a physical or mental impairment

- that substantially limits

- one or more major life activities.

The second and third parts of the definition cover persons who may not have any impairment that substantially limits a major life activity but who have a history of, or have been misclassified as having, such a substantially limiting impairment, or who are perceived as having such a substantially limiting impairment. The focus under this second category is on the reactions of other persons to a history of impairment or to a perceived impairment. A history or perception of an impairment that substantially limits a major life activity is a "disability." This falls under the Regulatory definition that entails a physical or mental impairment. Under this definition the following people are considered disabled: people with physiological disorder and those with cosmetic disfigurements.

9 These definitions by ADA were meant to create a civil law frame work, with the objective of having the protective frame work and aiming to eliminate all forms of discrimination to the class of persons listed there in. It also intended to have persons with disability represented in the main areas, especially in new advances in medical science, and affording them opportunities in all spheres of life including space frontiers. It was intended to be flexible, with new laws being strengthened and not 
weakened by future case laws. It was signed by President G.W. Bush and came into operation in 2008.

The definition of the term, "disability" under the Kenyan jurisdiction is found under section 2, of the persons with disability act, ${ }^{3}$ as amended in 2007. It states: that "disability" means a physical, sensory, mental or other impairment, including any visual, hearing, learning or physical incapability, whether arising from natural or artificial causes, which is irreversible and long term and which impacts adversely on a person's capacity to participate in social, economic, cultural or political activities. The act is further given priority as enshrined by the bill of rights in the Constitution of Kenya $^{4}$ under Article 54, which provides specific protection of fundamental rights to the class of persons with disability. The article provides inter alia:

- The right to be addressed and treated in a dignified manner.

- The right to education and provision of education services in a manner that caters for the needs of the individual in question.

- The right to reasonable access to all public places and places of leisure and recreation; this might include sporting facilities, recreational parks, restaurants, etc.

- The right to use a language that the persons understand and use e.g.Braille and sign language.

- The right to use accessible technology and devices that will assist the individual overcome his disability.

- The right to progressive employment up to $5 \%$ by the government.

11 These among others are provided for and the legal backing exists, under the stated law and other acts, to help improve the enforcement of PwD's rights.

The above stated definitions are legal in nature, and may differ to some degree, to the social or academic definitions of the term "disability" as noted by the UNPWD convention. It is also dynamic and it may be altered slightly from time to time depending on the changes in the fields of science and medicine. The Kenyan act also amended the legal meaning of the term through the "2007 amendment, from the principal document of 2003." Therefore it suffices to say that this concept is a dynamic one and we should be keen enough to determine its application when interpreting it.

\section{BIBLIOGRAPHY}

Americans with Disability Act, 1990.

The Persons with Disability Act of Kenya, 2003.

The Constitution of Kenya, 2010.

United Nations Standard Rules on Equalization of Opportunities, 1993.

United Nations Convention on Persons with Disability, 2008. 


\section{NOTES}

1. This UN Convention had been ratified by 153 countries by $12^{\text {th }}$ April, 2012 .

2. ADA was enacted by the $101^{\text {st }}$ American Congress in 1990.

3. The principal act, amended in 2007.

4. Current Constitution of Kenya, promulgated in August 2010.

INDEX

Geographical index: Kenya

\section{AUTHOR}

\section{STANLEY MUTUMA}

Stanley Mutuma is a lawyer who lost his sight during the 1998 American bombing incident; he did some rehabilitation and went on to study law. He is currently working at the judiciary and is also involved in paralympic sports. 